\title{
SEED GERMINATION OF A RARE NEOTROPICAL CANOPY TREE DORMANCY AND THE EFFECTS OF ABIOTIC FACTORS ${ }^{1}$
}

\author{
Flavio Nunes Ramos² e Antonio Carlos Silva de Andrade ${ }^{3}$
}

\begin{abstract}
The purpose of this study was to examine if germination is a critical phase on Enterolobium glaziovii regeneration. Hence, the germinative response of E. glaziovii seeds was investigated in relation to some of the main environmental factors (temperature, light and water stress) to which its seeds are subjected in the forest, as well as its dormancy and the longevity of its burial seeds. According to our results, its seeds may be regarded as photoblastic neutral. They do not need alternating temperatures to germinate and can germinate under a broad range of water stress. However, only about $10 \%$ of E. glaziovii seeds remain viable after one year. In other words, the annual fruiting, instead seed longevity, seems to maintain the long-term seed availability of this species. Consequently, the seed longevity could be a critical phase of E. glaziovii germination.
\end{abstract}

Keywords: Ecophysiology, Enterolobium glaziovii and Light.

\section{GERMINAÇÃO DE SEMENTES DE UMA ÁRVORE TROPICAL RARA DORMÊNCIA E EFEITO DE FATORES ABIÓTICOS}

\begin{abstract}
RESUMO - A ecologia da germinação de E. glaziovii é desconhecida e pode ser uma fase crítica de sua regeneração, uma vez que nem o crescimento nem a sobrevivência de juvenis ao redor de plantas reprodutivas são fases críticas da regeneração desta espécie rara. O objetivo deste trabalho foi examinar se a germinação é uma fase crítica da regeneração de Enterolobium glaziovii. Portanto, a resposta germinativa de sementes E. glaziovii foi investigada em relação a alguns dos principais fatores ambientais (temperatura, luz e estresse hídrico) a que suas sementes estão submetidas na floresta, assim como a dormência e longevidade de suas sementes enterradas. De acordo com os resultados, suas sementes podem ser classificadas como fotoblásticas neutras, pois não necessitam de temperaturas alternadas e podem germinar sob grande amplitude de estresse hídrico. Porém, apenas cerca de 10\% das sementes de E. glaziovii se mantiveram viáveis após um ano, ou seja, a frutificação anual, em vez da longevidade das sementes, parece manter a disponibilidade de sementes emo longo prazo dessa espécie. Consequentemente, a longevidade das sementes pode ser uma fase crítica da germinação de E. glaziovii.
\end{abstract}

Palavras-chave: Altas temperaturas, Ecofisiologia e Enterolobium glaziovii.

\section{INTRODUCTION}

Seed germination is one of the most crucial and decisive phases for a plant species in establishing itself and growing under a set of environmental conditions, such as light, temperature variation, and water availability (FENNER and THOMPSON, 2005). Understanding seed ecology, a broad field encompassing processes associated with seed production, dispersal, predation and germination, are important prerequisites to understanding recruitment and regeneration in plant populations
(PEARSON et al., 2002; CERVERA et al., 2006; SOUSA et al., 2008). Seed ecology provides an essential knowledge of population dynamics regarding the establishment of new individuals, and therefore the funding of new populations (REES, 1996; GODÍNEZALVAREZ et al, 1999; VALVERDE et al. 2004).

The analysis of the species' features that determine their distribution, abundance and habitat specificity has long been the core of ecological research (KREBS, 1994). These ecological aspects determine a species'

\footnotetext{
${ }^{1}$ Recebido em 11.02.2009 e aceito para publicação em 02.03.2010.

${ }_{2}$ Universidade Federal de Alfenas, UNIFAL/MG, Brasil. E-mail: <fnramos@gmail.com>.

${ }^{3}$ Instituto de Pesquisas Jardim Botânico do Rio de Janeiro, Diretoria de Pesquisa Científica, RJ, Brasil. E-mail: <candrade@jbrj.gov.br> .
} 
level and type of rarity (RAWINOWITZ, 1981). This subject is considered of great relevance in the context of conservation biology, because a large number of endangered species are naturally rare and therefore more prone to decline and extinction than relatively more common ones (GASTON, 1994). A species is considered rare when its populations are biologically viable but naturally sparse, frequently limited in its distribution range and/or occupying specific habitats (RAMÍREZ-PADILLA and VALVERDE, 2005).

The reproductive biology and the requirements for seed germination may play an important role as causal factors for limited abundance or restricted distribution ranges (RAMÍREZ-PADILLA and VALVERDE, 2005). Seed germination responses have a direct impact on a species' distribution and abundance, since it is a key element affecting population dynamics (GODINEZ-ALVAREZ et al., 1999; VALVERDE et al., 2004, RAMÍREZ-PADILLA \& VALVERDE, 2005).

Enterolobium glaziovii Bentham (Mimosaceae) is a rare canopy tree (Ramos et al. 2005a,b), endemic of the Brazilian Coastal Atlantic forests. This species occurs at low density, however, neither the growth nor survival of E. glaziovii offspring around conspecific adult trees are critical phases of its regeneration (Ramos et al, 2005a,b). Germination could be another possible phase that restrains regeneration of E. glaziovii. Knowledge of a critical factor that could inhibit or favor E. glaziovii germination may be important to conservation programs. Hence, the germinative response of E. glaziovii seeds was investigated in relation to some of the main environmental factors, including temperature, light and water stress, to which its seeds are subjected in the forest, as well as the dormancy and longevity of its burial seeds.

The purpose of this study was to study the germination responses to different factors of Enterolobium glaziovii (Benth.) Mesquita under controlled conditions to evaluate if their germination responses to these experimental factors are related to its rarity. The specific questions are: (1) Is seed coat responsible for seed dormancy?; (2) How do patterns of seed longevity in the soil vary?; (3) Are seeds capable of germinating in darkness?; (4) Are seeds capable of germinating under different temperatures? and (5) Are their seeds capable of germinating under different drought intensity?

\section{MATERIALS AND METHODS}

Mature fruit of E. glaziovii were collected on the floor (just after seed rain) under the only three individuals known at the Biological Reserve of Poço das Antas, (22.29' - 22。36’S, 42。13' - 42。21'W) Rio de Janeiro, SE, Brazil (RAMOS et al. 2005 a, b). The experiments were carried out in the Seed Laboratory of the Rio de Janeiro Botanical Garden after the seeds had been taken from the fruits. To prevent fungal infection, seeds were previously treated with sodium hypochlorite (10\% v/v; Vetec Inc., Brazil) for 10 minutes, followed by rinsing three times in distilled water being stored at $15^{\circ} \mathrm{C}$ in darkness, for periods ranging from 3 to 10 days, without any drying treatment. Seeds were selected eliminating those infested by insects or deteriorated.

\subsection{Fruit and seed characteristics}

Non-moldy and insect-free fruit were used to determine the mass of fruit and seeds, the seed / fruit ratio, as well as the fruit and seed size with the aid of a calliper. Seed water content was determined using five replicates of five seeds cut in quarters, using a dry oven at $105^{\circ} \mathrm{C}$ for 24 hours according to Ramos et al. (2000).

\subsection{Germination tests}

Germination tests were performed in transparent plastic boxes (gerbox) filled with heat-sterilized vermiculite, under temperature and light control chambers, with temperature kept constant within \pm $1{ }^{\circ} \mathrm{C}$ and, unless light was an intended variable, an $8 \mathrm{~h}$ light/16 h darkness regime ( 4 x 20W white fluorescent tubes; total fluence rate $\left.90 \mathrm{mmol} \mathrm{m}^{-2} \mathrm{~s}^{-1}\right)$. For the water stress experiments, two filter papers wet in distilled water or osmotic solution were used instead of vermiculite. For all experiments, percentage values are means of four replicates of 25 seeds.

Number of germinated seeds was recorded three times a week, until all the seeds germinated or died. The criterion for germination was visible radicle protrusion. Seeds showing external signs of rotting were considered dead.

\subsubsection{Seed dormancy}

Scarified and non-scarified seeds were germinated at $25^{\circ} \mathrm{C}$. Seeds were scarified in the opposite side of the radicle, with wood sandpaper. 


\subsubsection{Effect of temperature}

Scarified seeds were germinated under constant (20, 25, 30 and $\left.35^{\circ} \mathrm{C}\right)$ and alternating temperatures (20-30 ${ }^{\circ} \mathrm{C}$ and $20-35{ }^{\circ} \mathrm{C}$ ) subjected to a 8/16 h thermoperiod, according to Andrade et al. (2006).

\subsubsection{Effect of light treatment regime}

Scarified seeds were germinated at $25^{\circ} \mathrm{C}$, in black and transparent plastic boxes. Seed germination recordings were carried out in a dark room using green safety light.

\subsubsection{Effect of the water stress}

Scarified seeds were germinated at $25^{\circ} \mathrm{C}$, in gerbox moistened with different osmotic potentials. Aqueous (distilled water) solutions of mannitol mixed after Nobel (2005) were used to exert osmotic potentials $\left(\mathrm{y}_{\mathrm{s}}\right)$ of $-0.2,-0.4,-0.8,-1.2,-1.6 ;-1.8$; and -2.0 MPa. In order to avoid evaporation losses, the plastic boxes were sealed with adhesive tape.

\subsubsection{Seed longevity}

Non scarified seeds were placed with vermiculite into small nylon mesh bags (mesh size $1 \mathrm{~mm}$ ) and they were buried at $3 \mathrm{~cm}$ below soil surface under the shade of an E. glaziovii adult tree. During 24 months, the bags were exhumed every 3 months, and the seeds were germinated at $25^{\circ} \mathrm{C}$, at the laboratory. At the end of the experiment, the seeds that did not germinate were cut open for examination using the tetrazolium test whether or not the non-germinated seeds had lost their viability or failed to germinate.

\subsection{Analys}

The rate of seed germination was estimated using the Index of Germination Speed(IGV)(LABOURIAU, 1970): $\mathrm{IGV}=1 / \bar{t}=\Sigma n i \Sigma n i t i$, where is the average germination time, $t_{i}$ is the number of days between the beginning of the experiment and the $i^{i^{t h}}$ observation, and $n_{i}$ is the number of seeds germinated within the time interval $t_{i-1}|-| t_{i}$. Vertical lines and \pm values represent one standard error.

Data were subjected to one-way ANOVA, two-way ANOVA or to $t$ test after the arcsin transformation. Tukey's multiple comparison procedure was used to compare significant differences between treatment means (ZAR, 1996). Whenever the result of a replicate was zero or $100 \%$ the relative values of $1 / 4 n$ or $1-1 / 4 n$ were used, respectively, to calculate proportions before transformation ( $n$ is the number of seeds per replicate; ZAR, 1996). Throughout, results in which $\mathrm{P}<0.05$ are reported as significant.

\section{RESULTS}

\subsection{Fruit and seed characteristics}

The E. glaziovii fruit are indehiscent, black, contorted woody, large ( $4.3-8.9 \mathrm{~cm}$ x $3.0-4.4 \mathrm{~cm})$ and heavy (14.6 $\mathrm{g} \pm 6.4)$. They contain $9.4( \pm 3.1)$ seeds per fruit. The seeds were $0.5-1.6 \mathrm{~cm} \times 0.5-0.6 \mathrm{~cm}, 0.1 \mathrm{~g}( \pm 0.02)$ and showed a $14.9 \%( \pm 0.8)$ water content. No record of seed predation inside the fallen fruit was obtained.

\subsection{Germination test}

\subsubsection{Seed dormancy}

The hard seed coat influenced E. glaziovii seed germination. Scarified seeds present a higher germination percentage $\left(\mathrm{T}_{6}=10.2 ; P=0.001\right)$ and germination rate $\left(\mathrm{T}_{3.6}=4.9 ; P=0.01\right.$ ) than non-scarified ones (Table 1 ).

\subsubsection{Effect of temperature}

E. glaziovii seeds did not need alternating temperatures to germinate. There was no difference in germination percentage of scarified seeds at constant

Table 1- Means ( \pm SD) of germination percentage (Germ) and rate (IGV) of non-scarified and scarified seeds; and of seeds germinated under different light regimes. Similar letters (upper-case for dormancy treatment, lower-case for light treatment) do not differ by t test. Both non-scarified and scarified seeds were incubated in light, while for the light/dark experiment all seeds were scarified.

Tabela 1 - Médio $( \pm D P)$ da porcentagem (Germ) e da taxa de germinação (IGV) de sementes escarificadas e não escarificadas, e de sementes germinadas sob diferentes regimes de luz. Letras similares (primeiros duas colunas para o tratamento dormência, terceira e quarta coluna para o tratamento luz) não diferem pelo teste $t$. Tanto as sementes não escafificadas quanto as escarificadas foram germinadas sob iluminação, enquanto que para o experiemento luz/escuro todas as sementes foram escarificadas.

\begin{tabular}{lcccc}
\hline & Non-scarified & Scarified & Light & Darkness \\
\hline Germ $(\%)$ & $12( \pm 5.6) \mathrm{A}$ & $71( \pm 8.9) \mathrm{B}$ & $82( \pm 4.0)$ a & $81( \pm 5.0)$ a \\
IGV $\left(\mathrm{d}^{-1}\right)$ & $0.12( \pm 0.03) \mathrm{A}$ & $0.20( \pm 0.01) \mathrm{B}$ & $0.17( \pm 0.02) \mathrm{a}$ & $0.18( \pm 0.01) \mathrm{a}$ \\
\hline
\end{tabular}


and alternating temperatures $\left(\mathrm{F}_{5,18}=0.25 ; P=0.93\right)$ (Figure 1), nevertheless germination rate was highest at $30{ }^{\circ} \mathrm{C}$ and lowest at $20^{\circ} \mathrm{C}\left(\mathrm{F}_{5,18}=7.26 ; P=0.001\right)$.

\subsubsection{Effect of the light regime}

Scarified seeds germinated at light and darkness did not present significant difference neither in its germination percentage $\left(\mathrm{T}_{6}=0.28 ; P=0.79\right)$, or rate $\left(\mathrm{T}_{6}=0.65 ; P=0.54\right)$ (Table 1$)$.

\subsubsection{Effect of the water stress}

Although the germination percentage decreased with lower osmotic potentials $\left(F_{7.24}=7.7 ; P=0.001\right)$, scarified seeds germinated at all osmotic treatments (Figure 2), even as strongly negative as - 2.0 MPa.

\subsubsection{Seed longevity}

E. glaziovii seeds remain viable after almost two years (Figure 3 ). Although more than $50 \%$ of them lost their viability in the first 6 months, and only about $10 \%$ of them remain viable after one year $\left(\mathrm{F}_{7,24}=72.8 ; P=0.001\right)$.

\section{DISCUSSION}

As well as other Enterolobium species (EIRA et al., 1993, LIMA et al., 1997, MALAVASI and MALAVASI, 2004), seeds of E. glaziovii present hard coats. Species with hard seed coats are common in many species of

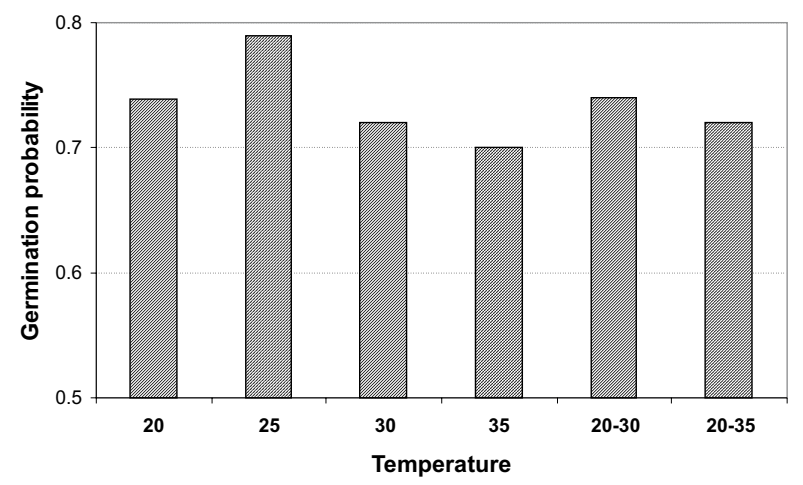

Figure 1- Germination probability of Enterolobium glaziovii Bentham seeds at constant and alternating temperatures. There was no difference among germination percentage.

Figura 1 - Probabilidade de germinação de Enterolobium glaziovii Bentham em temperaturas constante e alternadas. Não houve diferença estatística entre porcentagem de germinação.

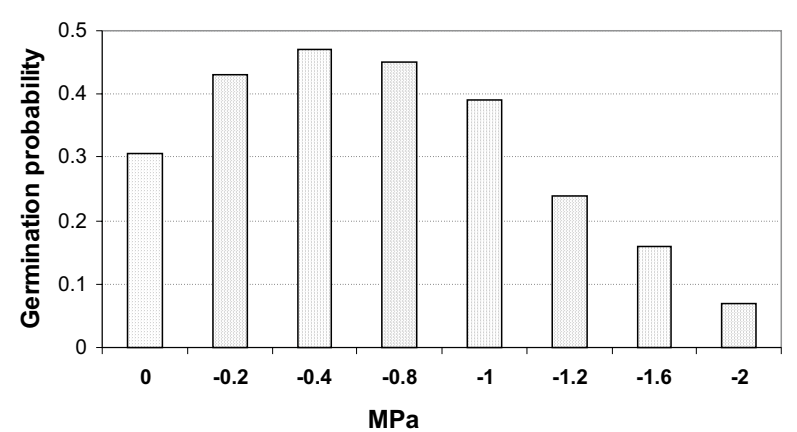

Figure 2 - Germination probability of Enterolobium glaziovii Bentham seeds submitted at different osmotic potentials.

Figura 2 - Probabilidade de germinação de sementes de Enterolobium glaziovii Bentham submetidas à diferentes potenciais osmóticos.

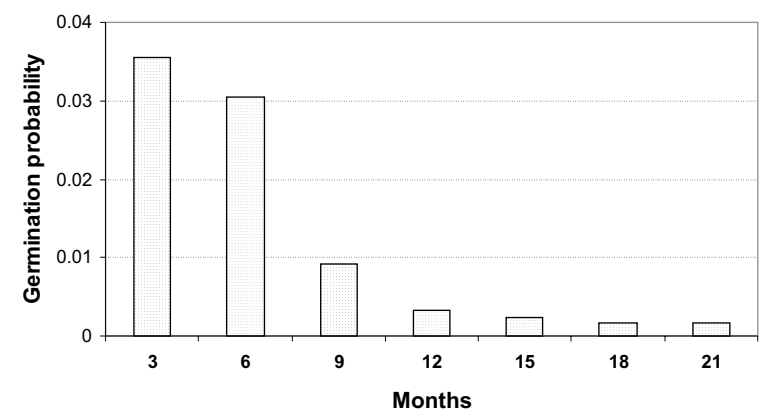

Figure 3 - Germination probability of Enterolobium glaziovii Bentham seeds buried in the soil for 3 to 21 months.

Figura 3 - Probabilidade de germinação de sementes de Enterolobium glaziovii Bentham enterradas no solo por 3 a 21 meses.

Leguminosae (BASKIN and BASKIN, 2001, 2004) tree species that produced these types of seeds and generally have low moisture content, high longevity, and take longer to germinate, like E. glaziovii (VAZQUEZ-YANES and OROZCO-SEGOVIA, 1984).

Following the dispersal of seeds in late autumn/ early winter, a majority of E. glaziovii seeds are dormant. When dormancy is broken, some seeds may germinate. In the laboratory, dormancy of E. glaziovii seeds could be overcome by mechanical scarification. This suggests that, in nature, seed dormancy may be ameliorated with mechanical abrasion, passage through the digestive tract of animals (BASKIN and BASKIN 2000), by fire or by microbial attack (BASKIN and BASKIN, 2000; TAYLOR, 2005) and, in some case, by high temperatures and thermal fluctuation 
experienced by seeds at or near the soil surface (VAZQUEZ-YANES and OROZCO-SEGOVIA, 1990; MORENO-CASASOLA et al., 1994).

Seeds that fail to germinate and that are not removed by seed predators can be incorporated into a seed bank, from which they may germinate later if various physiological requirements are met. Such requirements are affected by the seed's broader physical and biological environment (WILLIS et al., 1997). Dormancy has often been described as a device optimizing the distribution of germination in time and space (MORENO-CASASOLA et al., 1994). The presence of a hard seed coat rendered permeable over time, and combined with heteromorphism in coat hardiness or degree of impermeability among seeds, may prolong its germination periods (VAZQUEZYANES and OROZCO-SEGOVIA, 1993; MATILLA et al., 2005). This behaviour is of considerable value since temporal dispersal often enhances the spread and colonizing potential of the species (VAZQUEZ-YANES and OROZCO-SEGOVIA, 1993; MORENO-CASASOLA et al., 1994). While the seeds are on the ground, they can be moved by rain and animals, so the dispersal time is effectively lengthened and the ultimate dispersal area enlarged. The lack of seasonal germination showed by experiment of seed longevity suggests that recruitment of E. glaziovii from seeds is likely to occur throughout the year, rather than during seasonal "pulses". Although this species increases and renews the seed stock, fruiting annually (RAMOS pers. obs.), only about $10 \%$ of $E$. glaziovii seeds remain viable after one year. In other words, the annual fruiting, instead of seed longevity, seems to maintain the long-term seed availability of this species. Consequently, the seed longevity could be a critical phase of E. glaziovii germination.

Further, it is not surprising that light and alternating temperatures failed to stimulate the germination of $E$. glaziovii seeds. Light (VAZQUEZ-YANES and OROZCOSEGOVIA, 1993) and fluctuating thermoperiods (DRAKE, 1993; MORENO-CASASOLA et al., 1994) are factors whereby seeds can detect shallow burial under soils that experience relatively large diurnal temperatures and light changes caused by sunlight in exposed sites, such as canopy gaps. Additionally, E. glaziovii is a shade tolerant tree, whose offspring are established above dense canopy coverage (>80\%) (RAMOS et al., 2005a). Moreover, seeds of E. glaziovii could germinate underground and under the litter, where temperatures are not high and light could be absent.
E. glaziovii seeds are also tolerant to a wide range of water stress. Water deficit could inhibit seed germination of many tree species, because water is the initial factor for seed germination and is directly and indirectly involved with subsequent germination metabolic stages (CAVALCANTE \& PEREZ, 1995). Certain species were able to germinate at low water potentials. The range of water stress tolerance is different, among leguminous species. While some of them present lower tolerance, such as Acacia tortilis that did not germinate in osmotic potential below -0.6 MPa (CHOINSKI AND TUOHY, 1991), other species present higher tolerance, such as bean seeds (-1.2 MPa, MACHADO NETO et al., 2006), Leucaena leucocephala (-1.4 MPa, CAVALCANTE AND PEREZ, 1995), Indigofera astragalina (-1.5 MPa, SY et al., 2001), Enterolobium contortisiliquum (-1.6 MPa, HEBLING AND PEREZ, 1997), Prosopis juliflora (-1.9 MPa, PEREZ AND MORAES, 1991) and E. glaziovii (-2.0 $\mathrm{MPa}$, present study). Since its germination is spread along the year, this tolerance could be very important to the E. glaziovii regeneration, because its seeds will be able to germinate even at times with low soil water potential. The replacement of osmotic liquids by distilled water did not change the pattern found in water stress, because the non-germinated seeds had lost their viability in each osmotic potential (data not showed).

In summary, E. glaziovii seeds are disseminated with a hard coat that inhibits water imbibition. Abrasion due to scarification of the E. glaziovii seed coat seems to be the most important requirement to its germination. Thus, seeds probably may not germinate readily in nature until the seed coats are made permeable by frugivorous vertebrates or weathering. Its seeds may be regarded as photoblastic neutral, so they do not need alternating temperatures to germinate and can germinate under a broad range of water stress. Due to its hard coat, E. glaziovii germination could be temporally distributed within a year, but could not maintain viable seeds in a soil seed bank for long periods. In other words, the annual fruiting, instead of seed longevity, seems to maintain the long-term seed availability of $E$. glaziovii on the seed bank. Consequently, the seed longevity could be a critical phase of E. glaziovii germination.

Revista Árvore, Viçosa-MG, v.34, n.3, p.443-449, 2010 


\section{ACKNOWLEDGEMENTS}

We are grateful to CNPq (Brazilian Research Council) for the research grant $n^{\circ} 104081 / 95-3$. We are especially grateful to Ana Paula M. Cruz, Alexandre F. de Souza, and Marta B. Loureiro for their helpful assistance in the measurements of the experiments. Thanks to Alexandre F. de Souza, Fabiano Micheletto, Tiago B. Quental and Jim Henson for valuable comments on the manuscript and for correcting the English.

\section{REFERENCES}

ANDRADE, A. C. S. et al. Substrato, temperatura de germinação e desenvolvimento pós-seminal de sementes de Dalbergia nigra. Pesquisa Agropecuária Brasileira, v.41, n 3, p.517523, 2006.

BASKIN, J. M.; BASKIN, C. C. Evolutionary considerations of claims for physical dormancybreak by microbial action and abrasion by soil particles. Seed Science Research v.10, n.4, p.409-413, 2000.

BASKIN, C. C. \& BASKIN, J. M. Seeds: ecology, biogeography, and evolution of dormancy and germination. San Diego: Academic Press, 2001.

BASKIN, J. M. \& BASKIN, C. C. A classification system for seed dormancy. Seed Science Research, v.14, n.1, p.1-16, 2004.

CAVAlCANTE, A. M. B. \& PEREZ, S. C. J. G. A. Efeitos dos estresses hídrico e salino sobre a germinação de sementes de Leucaena leucocephala. Pesquisa Agropecuária Brasileira, v.30, p.281-289, 1995.

CERVERA, J. C. et al. Microhabitats, germination, and establishment for Mammillaria gaumeri (Cactaceae), a rare species from Yucatan. International Journal Plant Sciences v.16, n.2, p.311-319, 2006.

CHOINSKI, J. S. \& TUOHY, J. M. Effect of water potential and temperature on the germination of four species of African savanna trees. Annals of Botany, v.68, p.227-233, 1991.

DRAKE, D. R. Germination requirements of Metrosideros polymorpha, the dominant tree of Hawaiian lava flows and Rain Forest.

Biotropica, v.25, p.461-467, 1993.
EIRA, M. T. S.; FREITAS, R. W. A. \& MELLO, C. M. C. Superação da dormencia de sementes de Enterolobium contortisiliquum -Leguminosae. Revista Brasileira de Sementes, v.15, v.1, p.177-181, 1993.

FENNER, M. \& THOMPSON, K. The ecology of seeds. Cambridge: Cambridge University Press, 2005. Páginas.

GASTON, K. J. Rarity. London, Chapman \& Hall, 1994. Páginas.

GODINEZ-ALVAREZ, H.; VALIENTE-BANUET, A. \& VALIENTE-BANUET, L. Biotic interactions and the population dynamics of the long-lived columnar cactus Neobuxbaumia tetetzo in the Tehuacan Valley, Mexico. Canadian Journal of Botany, v.77, p.203-208, 1999.

HEBLing, S. A. \& PEREZ, S. C. J. G. A. Aspectos ecofisiológicos da germinação de sementes de Enterolobium contortisiliquum (Vellozo) Morong. 1997. Paginas. (PhD Thesis) - Universidade Federal de São Carlos, São Carlos, 1997.

KREBS, C. J. Ecology: the experimental analysis of distribution and abundance. 4.ed. New York: Harper Collins, 1994. Páginas.

LABOURIAU, L. G. On the physiology of see germination in Vicia graminea S.M.-I. Anais da Academia Brasileira de Ciências, v.42, p.235-262, 1970.

LIMA, C. M. R.; BORGHETTI, M.; SOUSA, M. V. Temperature and germination of the leguminosae Enterolobium contortisiliquum. Revista Brasileira de Fisiologia Vegetal, v.9, n.1, p.97-102, 1997.

MACHADO NETO, N. B. et al. Deficiência hídrica induzida por diferentes agentes osmóticos na germinação e vigor de sementes de feijão. Revista Brasileira de Sementes v.28, p.142-148, 2006.

MALAVASI, U. C.; MALAVASI, M. M. Dormancy breaking and germination of Enterolobium contortisiliquum (Vell.) Morong seed.

Brazilian Archives of Biology and Technology, v.47, p.851-854, 2004. 
MATILLA, A.; GALLARDO, M. \& PUGA-HERMIDA, M. I. Structural, physiological and molecular aspects of heterogeneity in seeds: a review. Seed Science Research, v.15, n.1, p.63-76, 2005.

MORENO-CASASOLA, P.; GRIME, J. P. \& MARTINEZ, M. L. A comparative study of the effects of flutuactions in temperature and moisture supply on hard coat dormancy in seeds of coastal tropical legumes in Mexico. Journal of Tropical Ecology, v.10, n.1, p.67-86, 1994.

NOBEL, P. S. Physicochemical and environmental plant physiology. 3.ed. San Diego: Elsevier/Academic Press, 2005.

PEARSON, T. R. H. et al. Germination ecology of neotropical pioneers: interacting effects of environmental conditions and seed size. Ecology, v.83, n 10, p.2798-2807, 2002.

PEREZ, S. C. J. G. A. \& MORAES, J. A. P. V. Influencia do estresse hidrico e do $\mathrm{pH}$ no processo germinativo de algarobeira. Pesquisa Agropecuária Brasileira, v.26, n 7, p.981-988, 1991.

RAMÍREZ-PADILLA, C.A. \& VALVERDE, T. Germination responses of three congeneric cactus species (Neobuxbaumia) with differing degrees of rarity. Journal of Arid Environments, v.61, n.2, p.333-343, 2005.

RAMOS, F. N. et al. Comparação entre métodos de secagem na determinação do grau de umidade em sementes de Parkia multijuga Benth. (Leguminosae Mimosoideae). Revista Arvore, v.24, n.1, p.175-179, 2000.

RAMOS, F. N.; SILVA MATOS, D. M. \& SANTOS, F. A. M. Spatial distribution of seeds and juveniles of Enterolobium glaziovii Bentham (Leguminosae, Mimosoideae) in the Atlantic forest, Brazil. Acta Botanica Brasilica, v.19, n 3, p.609-614, 2005a.

RAMOS, F. N.; SILVAMATOS, D. M. \& SANTOS, F.A. M. Juvenile dynamics of the endemic and rare Enterolobium glaziovii (Mimosaceae) around reproductive trees in the Atlantic Forest, Brazil. Revista Brasileira de Botanica, v.28, p.765-772. 2005b.

RAWINOWITZ, D. Seven forms of rarity. In: SYNGE, H. (Ed.) The biological aspect of rare plant conservation. New York: Wiley,1981. p.205-217.
REES, M. Evolutionary ecology of seed dormancy and seed size. Phillosophical Transaction of Royal Society London, Serie B, v.351, n 1345, p.1299-1308, 1996.

ROLSTON,M. P. Water impermeable seed dormancy. Botanical Review, v.44, n 3, p.365-396, 1978.

SOUSA, M. P. et al. Germinação de sementes de Plantago ovata Forsk. (Plantaginaceae): temperatura e fotoblastismo. Revista Árvore, v.32, n.1, p.51-57, 2008.

SY, A.; GROUZIS, M.; DANTHU, P. Seed germination of seven Sahelian legume species. Journal of Arid Envinronment, v.49, n.4, p.875-882, 2001.

TAYLOR, G. B. Hardseededness in Mediterranean annual pasture legumes in Australia: a review. Australian Journal of Agricultural Research, v.56, n 7, p.645-661, 2005.

WILLIS, A. J.; GROVES, R. H. \& ASH, J. E. Seed ecology of Hypericum gramineum, an Australian Forb. Australian Journal of Botany, v.45, n 6, p.1009-1022, 1997.

VALVERDE, T.; QUIJAS, S.; LÓPEZ-

VILLAVICENCIO, M. \& CASTILLO, S. Population dynamics of Mammillaria magnimamma Haworth (Cactaceae) in a lava-field in Central Mexico.

Plant Ecology, v.170, n.1, p.167-184, 2004.

VAZQUEZ-YANES, C. \& OROZCO-SEGOVIA,A. Ecofisiology of seed germination in the tropical humid forest of the word: a review. In: MEDINA, E.; HOONEY, H. A. \& VASQUEZYANEZ, C. (Eds). Physiological ecology of plants of the wet tropics. The Hague, Dr W Junk, 1984. p.37-50.

VAZQUEZ-YANES, C. \& OROZCO-SEGOVIA,A. Seed dormancy in the tropical rain forest. In: BAWA K. S. \& HADLEY, M. Reproductive ecology of tropical forest plants. Paris/ Carnforth: UNESCO/ Pathernon, 1990. p.247-260.

VAZQUEZ-YANES, C. \& OROZCO-SEGOVIA,A. Patterns of seed longevity and germination in the tropical rainforest. Annual Review of Ecology and Systematics, v.24, n.1, p.69-87, 1993.

ZAR, J. H. Biostatistical analysis. New Jersey: Prentice Hall, 1996.

Revista Árvore, Viçosa-MG, v.34, n.3, p.443-449, 2010 